\title{
Analisis Buku Ajar Bahasa Arab Madrasah Aliyah Kurikulum 2013
}

\author{
Sutri Ramah \\ MTs Yasmida Ambarawa Pringsewu Lampung \\ sutrirahma1@gmail.com \\ Miftahur Rohman \\ Universitas Islam Negeri (UIN) Raden Intan Lampung \\ miftabur1robman@gmail.com
}

\begin{abstract}
Content analysis is a method to study and analyze something that systemically and objectively on the message that appears. The contents of textbooks are a source of material in the learning process. Therefore, textbooks must be in accordance with the applicable curriculum. In the context of education in Indonesia, the current curriculum is the 2013 curriculum with a scientific approach. This study sought to find out the content of the material (biwar and qira'ah) of Arabic students' books 2013 curriculum of the grade XII MA published by the Ministry of Religion and its suitability with the 2013 curriculum which consisted of four Core Competencies which became the perspective. The approach used is a qualitative-descriptive approach using documentation and content analysis methods as a tool for collecting and analyzing data. The results of this study is indicate material content (biwar and qira'ah) in accordance with the 2013 curriculum content standard. The details are as follows: 1) the first chapter of the more prominent aspects is the realm of spiritual attitude and knowledge; 2) chapter two, Knowledge and Skills; 3) chapter three, Social Attitudes and Knowledge; 4) chapter four, the domain of Social Attitudes; and 5) Spiritual Attitudes. From the research findings, the social attitude in this book is very minimal. Aspects of diversity, tolerance, pluralism and multiculturalism are not found in the material of the book.
\end{abstract}

Keywords: Analysis, textbooks, Curriculum 2013

\begin{abstract}
Abstrak
Analisis isi merupakan suatu metode untuk mempelajari dan menganalisa sesuatu secara sistemik dan objektif terhadap pesan yang tampak. Isi buku pelajaran merupakan sumber materi dalam proses pembelajaran. Oleh karena itu, buku pelajaran harus sesuai
\end{abstract}


dengan kurikulum yang berlaku. Dalam konteks pendidikan di Indonesia, kurikulum yang berlaku saat ini adalah kurikulum 2013 dengan pendekatan saintifik. Penelitian ini berusaha mengetahui isi materi (biwar dan qiraah) buku bahasa Arab siswa kurikulum 2013 kelas XII MA terbitan Kementerian Agama dan kesesuaiannya dengan kurikulum 2013 yang terdiri dari empat Kompetensi Inti (KI) yang menjadi perspektifnya. Pendekatan yang digunakan adalah pendekatan deskriptif-kualitatif dengan menggunakan metode dokumentasi dan analisis isi (content analysis) sebagai alat untuk mengumpul dan analisis data. Hasil penelitian ini menunjukkan konten materi (biwar dan qira'ab) telah sesuai dengan Standar Isi (KI) kurikulum 2013. Rinciannya sebagai berikut: 1) bab pertama aspek lebih menonjol adalah ranah Sikap Spiritual (KI 1) dan Pengetahuan (KI 3); 2) bab dua, ranah Pengetahuan (KI 3) dan Keterampilan (KI 4); 3) bab tiga, ranah Sikap Sosial (KI 2) dan Pengetahuan (KI 3); 4) bab empat, ranah Sikap Sosial (KI1); dan 5) Sikap Spiritual (KI 2). Dari hasil temuan penelitian, ranah Sikap Sosial (KI 2) dalam buku ini sangat minim. Aspek keragaman, toleransi, pluralisme, dan multikulturalisme tidak ditemukan dalam materi buku tersebut.

Kata Kunci: Analisis, Buku Ajar, Kurikulum 2013

\section{Pendahuluan}

Rendahnya kemampuan literasi siswa dipengaruhi oleh banyak faktor, antara lain: kurikulum dan sistem pendidikan, pemilihan metode dan model pengajaran oleh guru, sarana dan fasilitas belajar, sumber belajar, buku ajar, dan lain sebagainya. Salah satu faktor yang secara langsung bersinggungan dengan kegiatan pembelajaran siswa dan mempengaruhi rendahnya kemampuan literasi siswa adalah keberadaan sumber belajar. Buku ajar merupakan salah satu aspek terpenting dalam pendidikan. Buku ajar baik yang berbentuk cetak, seperti buku maupun non-cetak (ebook, internet, video, rekaman) memainkan peran yang cukup substansial dalam ketercapaian tujuan pembelajaran. ${ }^{1}$ Kesesuaian Buku ajar dengan standar isi yang diterapkan oleh pemerintah menjadi sebuah keharusan selain pelbagai faktor lain, seperti media belajar, sarana dan prasarana, serta iklim pembelajaran yang kondusif.

Beberapa waktu lalu ditemukan buku ajar yang tidak sesuai dengan standar isi dalam kurikulum. Buku ajar tersebut diduga mengandung muatanmuatan negatif yang menyimpang dari norma-norma kesusilaan, seperti kasus

${ }^{1}$ Feni Kurnia and Apit Fathurohman, "Analisis Bahan Ajar Fisika Sma Kelas Xi Di Kecamatan Indralaya Utara Berdasarkan Kategori Literasi Sains," Jurnal Inovasi dan Pembelajaran Fisika 1, no. 1 (2014), hlm. 43-47. 
yang ditemukan di Bogor ${ }^{2}$, Jakarta ${ }^{3}$, Malang $^{4}$, dan Banyumas ${ }^{5}$. Selain contohcontoh kasus tersebut juga ditemukan kasus buku ajar yang mengandung muatan-muatan radikalisme. Dengan demikian, penyediaan buku ajar terutama untuk pendidikan dasar dan menengah masih menyisakan problem yang perlu diatasi.

Ditemukannya buku-buku ajar yang memuat konten-konten pornografi dan radikalisme di atas, serta tidak sesuai dengan kaidah dan standar isi kurikulum tentu cukup riskan jika diabaikan, mengingat buku ajar sekolah adalah buku pokok yang tentu dibaca dan diinternalisasi oleh siswa-siswa. Oleh karena itu, buku ajar yang digunakan perlu dianalisis, apakah sudah memenuhi kriteria sebagai buku yang layak atau belum, tepat sasaran atau tidak, dan sebagainya. Analisis dilakukan terutama berkaitan dengan konten materi yang disajikan. Analisis terhadap konten buku ajar perlu dilakukan untuk memastikan kualitas dan kelayakan buku tersebut untuk digunakan. Lebih-lebih dalam kurikulum 2013 yang menggunakan pendekatan saintifik yang berpusat pada siswa.

Terkait dengan analisis buku ajar bahasa Arab, telah ditemukan beberapa penelitian terdahulu yang menelaah kelayakan buku ajar bahasa Arab, seperti analisis kesalahan penerapan qawä'id buku ajar bahasa Arab untuk pendidikan dasar dan menengah, ${ }^{6}$ analisis materi ajar bahasa Arab untuk madrasah ibtidaiyah, ${ }^{7}$ dan studi komparasi perbandingan kualitas buku teks bahasa Arab

2 Kasus tersebut ditemukan tahun 2013 SDN IV dan Gunung Gede, Kota Bogor. Ditemukan unsur pornografi pada buku paket pelejaran Bahasa Indonesia untuk siswa kelas VI. Lihat Zaki Al Hamzah, "Beredar Buku Pelajaran SD Berbau Porno," http://m.republika.co.id/berita/koran/news-update/13/07/10/mpg3lg-beredar-bukupelajaran-sd-berbau-porno, diakses tanggal 11 Agustus 2018 .

3 Pada Februari 2017 di Jakarta ditemukan konten pornografi dalam buku yang berjudul 'Aku Berani Tidur Sendiri'. Lihat Muhammad Taufiqurrahman, "Menko Puan Minta Buku 'Aku Berani Tidur Sendiri' Diinvestigasi,” http://m.detik.com/news/berita/d3428466/menko-puan-minta-buku-aku-berni-tidur-sendiri-diinvestigasi, diakses 11 Agustus 2018.

${ }^{4}$ Pada awal tahun 2016 Kota Malang dihebohkan dengan cover LKS untuk SD bertulis aksara Jawa yang jika diartikan adalah alat kelamin pria. M. Sanusi, "Heboh! LKS Berbau Pornografi Di Malang," http://daerah.sindonews.com/read/ 1086437/heboh-lks-bahasa-jawamesum-di-kota-malang, diakses 12 Agustus 2018.

${ }^{5}$ Buku yang ditemukan mengandung unsur pornografi di Banyumas pada Desember 2016 adalah buku Penjaskes untuk SD kelas V. Lihat Salahudin, "Ada Unsur Porno, Buku Penjasorkes SD Kelas V Di Banyumas Ditarik,” http://daerah.sindonews.com/ $\mathrm{read} / 11608653 / 22 /$ ada-unsur-porno-buku-penjasorkes-untuk-sd-kelas-v-di-banyumas-di-tarik, diakses 12 Agustus 2018.

${ }^{6}$ Muhammad Afif Amrullah, "Analisis Kesalahan Penerapan Qawa'id Pada Buku Ajar Bahasa Arab,” Al-Tadzkizyah: Jurnal Pendidikan Islam 6, no. 1 (2017), hlm. 46-65.

7 Rini Dwi Susanti, "Studi Analisis Materi Ajar "Buku Teks Pelajaran "Pada Mata Pelajaran Bahasa Arab di Kelas Tinggi Madrasah Ibtidaiyah,” Arabia 5, no. 2 (2016), h. 199-223. 
untuk madrasah tsanawiyah. ${ }^{8}$ Dari hasil penelitian-penelitian tersebut didapati problem dalam buku ajar bahasa Arab di madrasah, seperti adanya kesalahan dalam pembuatan qawa'id, standar kompetensi dengan kedalaman materi yang masih kurang, dan kurang menariknya tampilan sebuah buku.

Buku bahasa Arab yang baik dapat dinilai dari empat aspek penilaian buku yang digagas oleh BSNP, yakni aspek isi, penyajian, bahasa, dan kegrafikan. Namun dalam penelitian ini, peneliti fokus mengkaji aspek isi yang meliputi kbiwär dan qiräah, karena sejauh ini belum ditemukan hasil penelitian yang khusus mengupas hal tersebut. Dengan demikian, rumusan masalah dalam penelitian ini adalah: bagaimana kualitas konten materi khiwär dan qiräăh buku ajar bahasa Arab kurikulum 2013 madrasah aliyah untuk kelas XII ditinjau dari empat kompetensi inti kurikulum 2013? Untuk itu, penelitian ini bertujuan menganalisis konten materi tersebut berdasarkan kompetensi inti kurikulum 2013 yang terdiri dari empat kompetensi: sikap spiritual, sikap sosial, pengetahuan, dan keterampilan. Adapun manfaat penelitian adalah untuk mengetahui konten materi khiwär dan qiräăh ditinjau dari perspektif kurikulum 2013. Sehingga dapat diketahui apakah terdapat konten materi yang belum pas dan perlu diadakan revisi untuk cetakan berikutnya. Selain itu, hasil penelitian ini diharapkan dapat menjadi masukan bagi para penulis dan penerbit buku untuk menerbitkan buku ajar yang baik serta berkualitas.

Dalam penelitian ini, penulis menggunakan pendekatan penelitian kualitatif dengan studi literatur (library research). ${ }^{9}$ Proses pengumpulan yang dilakukan dengan catatan dokumentasi yang berupa data-data tertulis terkait materi khiwär dan qiräah buku ajar bahasa Arab siswa kurikulum 2013 kelas XII terbitan Kementerian Agama. Selanjutnya, analisis isi (content analysis) digunakan untuk menggali dan menganalisis muatan-muatan isi dari sebuah teks biwär dan qiräah tersebut untuk melihat kesesuaiannya dengan kurikulum 2013 yang menjadi perspektifnya. ${ }^{10}$ Di tahap akhir, penarikan kesimpulan dilakukan untuk melihat tema-tema materi dalam khiwär dan qiräah yang mencakup ranah spiritual, sosial, dan pengetahuan.

\section{Urgensi Buku Ajar dalam Pembelajaran}

Buku ajar memiliki padanan dalam bahasa Inggris dengan textbook atau dalam bahasa Arab dengan al-Kitäb al-Madrasiy (الكتاب المدرسي) adalah buku yang berisi materi pelajaran, disusun sedemikian rupa sehingga siswa mudah

8 M Syamsul Ma'arif, "Perbandingan Kualitas Buku Teks Bahasa Arab Tingkat Madrasah Tsanawiyah," Jurnal Pendidikan Islam 4, no. 1 (2015), hlm. 209-234.

9 Sartono Kartodirdjo and Sarwono Pusposaputro, Pendekatan Ilmu Sosial dalam Metodologi Sejarah (Gramedia Pustaka Utama, 1992), hlm. 70.

10 Stefan Sticsher, Metode Analisis Teks \& Wacana, Terj. Gazali Dkk (Yogyakarta: Pustaka Pelajar, 2009), hlm. 97. 
memahami materi tersebut dalam proses belajar mengajar di bawah bimbingan seorang guru. Buku ajar merupakan komponen yang sangat penting dalam proses pembelajaran. Tanpa melibatkan buku ajar, pembelajaran bisa menjadi kurang optimal dan tak terarah. Karena buku ajar adalah sumber bahan pembelajaran dan sumber informasi utama yang mendukung proses pencapaian tujuan pembelajaran yang disusun, didistribusikan, dan digunakan dalam pembelajaran sesuai dengan kurikulum yang digunakan. ${ }^{11}$

Chambliss dan Calfee dalam Masnur Muslich menjelaskan lebih lanjut, buku ajar atau buku teks adalah alat bantu siswa untuk memahami dan belajar dari hal-hal yang dibaca dan untuk memahami dunia di luar dirinya. Menurut mereka, buku teks mempunyai kekuatan yang luar biasa besar terhadap perubahan otak siswa dan acap kali dapat memengaruhi pengetahuan anak terhadap nilai-nilai tertentu. Selain itu, buku ajar juga menjadi pegangan wajib bagi siswa maupun guru demi kelancaran pengelolaan kelas. ${ }^{12}$

Sementara itu, menilik Peraturan Menteri Pendidikan dan Kebudayaan (Kemendikbud) Nomor 8 Tahun 2016, buku teks pelajaran merupakan perangkat operasional utama atas pelaksanaan kurikulum dan buku non-teks pelajaran merupakan sarana pendukung untuk memfasilitasi pelaksanaan, penilaian, dan pengembangan pembelajaran bagi peserta didik dan pendidik, sehingga harus memenuhi kriteria buku yang layak digunakan satuan pendidikan. Buku ajar juga merupakan wujud pelayanan satuan pendidikan terhadap peserta didik. Pelayanan individual dapat terjadi dengan buku ajar. Karena, peserta didik akan berhadapan dengan bahan yang terdokumentasi yang memuat informasi pelajaran. Peserta yang cepat belajar akan dapat mengoptimalkan kemampuannya dengan mempelajari buku ajar. Sebaliknya, peserta didik yang lambat belajar akan dapat mempelajari buku ajarnya berulang-ulang. ${ }^{13}$ Dengan demikian, buku ajar memainkan peran yang cukup krusial dalam pembelajaran.

Buku ajar sebagai unsur sumber daya pendidikan tentunya memiliki peran penting dalam mempengaruhi keberhasilan suatu pembelajaran. Demikian pula pada mata pelajaran bahasa Arab juga keberhasilan pembelajarannya tidak bisa terlepas dari keberadaan suatu buku pelajaran. Buku ajar juga sebagai pusat atau sumber informasi dan ilmu pengetahuan yang mampu memberikan aktivitas transformasi suatu pengetahuan. Agar pencapaian pembelajaran mendapatkan hasil yang baik, maka salah satu komponennya sangat bergantung pada kualitas buku pelajaran yang ada.

${ }^{11}$ Khairy Abusyairi, "Pengembangan Baban Ajar Babasa Arab," Dinamika Ilmu 13, no. 1 (2013), hlm. 51-66.

12 Masnur Muslich, Text Book Writing: Dasar-Dasar Pemahaman, Penulisan, Dan Pemakaian Buku Teks, Ar-Ruгz Media (Yogyakarta, 2010), hlm. 47-52.

${ }^{13}$ Peraturan Menteri Pendidikan and Kebudayaan Nomor 8 Tahun 2016 Tentang Buku Yang Digunakan Oleh Satuan Pendidikan. 


\section{Karakteristik Buku Ajar Bahasa Arab}

Sebagai buku referensi belajar, buku ajar bahasa Arab memiliki karakteristik tersendiri yang berbeda dengan jenis buku lainnya, seperti buku fiksi atau buku bacaan biasa. Secara umum, buku teks merupakan karya tulis ilmiah. Oleh sebab itu, karakteristik buku teks sama dengan karya ilmiah. Dari segi isi, buku teks berisi seperangkat pengetahuan atau informasi yang dapat dipertanggungjawabkan keilmiahannya. Dari segi sajian, materi dalam buku teks disajikan dengan pola penalaran tertentu, sebagaimana pola penalaran ilmiah (induktif, deduktif, atau campuran. Sedangkan dari segi format, buku teks mengikuti konvensi buku ilmiah, baik dari segi pola penulisan, pola pengutipan, pola pembagian, maupun pola pembahasannya

Menurut Iskandar dan Dadang Sunendar, setidaknya ada empat hal yang harus diperhatikan dalam menetapkan buku ajar, yaitu: pertama, materi pelajaran hendaknya sesuai dengan kurikulum sehingga dapat menunjang tercapainya tujuan instruksional. Kedua, materi pelajaran hendaknya sesuai dengan tingkat pendidikan dan perkembangan peserta didik pada umumnya. Ketiga, materi pelajaran hendaknya tersusun secara sistematik dan berkesinambungan. Keempat, materi pelajaran hendaknya mencakup hal-hal yang bersifat faktual dan konseptual, merujuk pada tujuan instruksional yang ingin dicapai, bermakna bagi peserta didik, serta baik dari tujuan yang hendak dicapai dan fungsinya. ${ }^{14}$

Selain itu, buku ajar dapat diaktualisasikan dalam mendukung desain pembelajaran bahasa Arab komunikatif, seperti audio lingual. Tujuan-tujuan komunikatif bisa dicapai terbaik dengan memberikan perhatian terhadap penggunaan bahasa dan bukan sekadar kegunaan, kelancaran berbahasa atau sekedar ketepatan terhadap bahasa dan konteks yang otentik. Para praktisi pembelajaran bahasa Arab komunikatif memandang urgen penggunaan bahan ajar sebagai cara untuk mempengaruhi kualitas interaksi komunikatif di dalam atau di luar ruangan terkait dengan penggunaan bahasa Arab. Dengan demikian, bahan ajar bahasa Arab memiliki peranan vital dalam usaha memotivasi peserta didik untuk mengaktualisasikan bahasa komunikatif. Desain pembelajaran ini sangat fokus pada tiga aspek: aspek bahan ajar berbasis teks, aspek bahan ajar berbasis tugas, dan aspek buku ajar berbasis realitas. ${ }^{15}$

Selanjutnya, karakteristik buku ajar bahasa Arab untuk siswa Arab (native) dan non-Arab, seperti pendidikan bahasa Arab di Indonesia, mempunyai karakteristik yang berbeda. Buku ajar bahasa Arab untuk siswa non-Arab hendaknya memperhatikan karakteristik bahasa, budaya, dan keadaan geografi

${ }^{14}$ Iskandar Wassid and Dadang Sunendar, Strategi Pembelajaran Babasa (Bandung: PT. Remaja Rosdakarya, 2008), hlm. 126.

15 Zulhanan Zulhanan, "Model Pembelajaran Bahasa Arab Komunikatif," Jurnal Al Bayan: Jurnal Jurusan Pendidikan Bahasa Arab 6, no. 2 (2017), hlm. 34-45. 
siswa setempat. ${ }^{16}$ Dalam hal ini sangat penting bagi penulis buku pendidikan, khususnya bahasa Arab, mempertimbangkan sejumlah aspek sebagai berikut:

1. Aspek Sosial-budaya

Hubungan antara bahasa dan budaya bersifat dialektis, tidak ada ekspresi budaya tanpa bahasa, dan tidak ada bahasa yang bisa diucapkan secara terpisah dari budaya. Bahasa adalah pot budaya dan instrumen pertamanya. Sedangkan untuk hubungan budaya dalam mengajar bahasa Arab ke peserta didik non-native memiliki arti bahwa budaya masyarakat Arab dan Islam sebagai bagian penting dari persyaratan belajar bahasa. Dalam linguistik sosial, pelajar bahasa asing harus mengenal budaya masyarakat dimana bahasa yang ingin dikuasainya dipelajari. ${ }^{17}$

2. Aspek Psikologis Siswa

Pendidikan modern menekankan peran peserta didik sebagai elemen aktif dalam semua kegiatan pendidikan. Hal ini merupakan fokus utama dari tujuan pendidikan. Oleh karena itu, belajar tentang karakteristik pelajar dari sudut pandang psikologis dan mental sangat penting dalam mempersiapkan dan menulis buku pendidikan. Terdapat perbedaan besar antara minat remaja dan orang dewasa dalam mempelajari bahasa asing. Salah satu ciri khas pembelajaran bahasa asing bagi siswa adalah adanya dorongan motivasi yang dapat diartikan sebagai perasaan batin yang terjadi pada individu dan tidak dapat diamati secara langsung, namun dapat disimpulkan dari perilaku yang nyata. Studi lapangan dalam pembelajaran bahasa asing telah menunjukkan hubungan dialektis antara belajar bahasa asing dengan motivasi peserta didik. Belajar bahasa asing tentu tidak mudah dan mudah karena mengandung proses mental dan bentuk usaha yang panjang dan membutuhkan banyak kesabaran. ${ }^{18}$ Oleh karena itu pentingnya motivasi diri dan peran utamanya dalam keberhasilan belajar bahasa asing, sehingga perlu untuk mengetahui motif-motif ini terlebih dahulu dalam menulis buku teks bahasa Arab sebagai bahasa asing.

3. Aspek Kebahasaan

Bahasa didefinisikan sebagai seperangkat sistem fonetik, gramatikal, morfologi, dan leksikal yang digabungkan untuk menghasilkan kalimat dan makna dan makna antara sekelompok orang tertentu. ${ }^{19}$ Dengan demikian, penulisan buku teks bahasa Arab hendaknya memperhatikan hal-hal tersebut. Selain itu, buku ajar bahasa Arab mencakup dasar-dasar linguistik bahasa yang

${ }^{16}$ Maufiq Abdullāh Al-Qashiri, Asytarāināi Maqtarahata Là 'adāda Al-Kitāb Al-Ta'limì Fì Al-Lughati Al-'Arabiyyah (Kuala Lumpur: al-Jami’ah al-Wathaniyah, n.d.), hlm.5.

${ }^{17}$ Ibid., hlm. 7.

${ }^{18}$ Ibid., hlm. 9.

${ }^{19}$ Ibid., hlm. 11 
meliputi suara, kosa kata, dan struktur bahasa yang disesuaikan dengan tingkat mental dan linguistik peserta didik.

Buku bahasa Arab yang baik harus mencakup materi-materi yang mendukung empat kemahiran berbahasa, yaitu kemahiran pengungkapan/speaking (mahärah al-ta'bir), kemahiran menyimak/listening skill (mahārah alistimā'), kemahiran membaca/reading skill (mahārah al-qiräah), dan kemahiran menulis/writing skill (mahärah al-kitäbah). ${ }^{20}$ Karena pelajaran bahasa Arab merupakan suatu mata pelajaran yang diarahkan untuk mendorong, membimbing, mengembangkan, dan membina kemampuan siswa terhadap bahasa Arab, baik reseptif maupun produktif. Kemampuan aktif dan pasif dalam berbahasa Arab tersebut sangat penting dalam membantu memahami al-Quran dan Hadis sebagai sumber utama ajaran Islam.

\section{Kesesuaian Isi Khiwār dan Qirā’ah Buku Bahasa Arab Kurikulum 2013 Kelas XII MA Terbitan Kemenag dengan Kompetensi Inti Kurikulum 2013}

Buku siswa bahasa Arab kurikulum 2013 untuk MA kelas XII ini terdiri dari $144+$ vi halaman. Halaman i-vi terdiri dari cover, identitas penulis dan penerbit, kata pengantar, dan daftar isi. Sedangkan halaman 1-144 adalah isi buku yang terdiri dari lima bab di mana pada tiap babnya tersusun dari mufradàt, biwār, tarkīb, qirāah, dan tadrīb. Di setiap awal bab, buku ini dilengkapi dengan penjelasan KI, KD, serta indikator dan tujuan pembelajaran. Buku ini ditulis oleh Ahmad Hidayat, S.Ag., dengan editor Dr. Muhbib Abdul Wahab, MA., dan diterbitkan oleh Direktorat Pendidikan Madrasah Ditjen Pendidikan Islam Kementerian Agama Republik Indonesia. Buku ini adalah edisi cetakan ke-1 tahun 2016 merupakan edisi revisi dari cetakan sebelumnya. Dengan memperhatikan identitas buku tersebut, buku ini tergolong baru dan baru digunakan pada tahun ajaran ini.

1. Isi Materi Buku

Buku ajar bahasa Arab ini terdiri dari lima bab pembahasan/tema yang disajikan ke dalam dua semester. Pada setiap babnya terdiri dari lima sub bab/komponen, yaitu mufradät, hiwār, tarkìb, qiräah, dan tadrīb. Dalam penelitian ini penulis memfokuskan analisis pada bagian biwär dan qiräah yang ditinjau berdasarkan kurikulum 2013 yang terdiri dari empat kompetensi inti: sikap spiritual dan sosial, pengetahuan, dan keterampilan. Selanjutnya, uraian tentang isi teks atau biwār dan qiräah dalam setiap bab di buku ini akan diuraikan sebagai berikut:

${ }^{20}$ Sembodo Ardi Widodo, "Model-Model Pembelajaran Bahasa Arab," Al-Arabiyyah jurnal PBA 2 (2006), hlm. 1-14. 


\section{a. Bab Pertama}

Bab pertama yang bertema الحضارة الإسلامية (Peradaban Islam) menjelaskan mengenai penemuan-penemuan ilmuan Muslim, terutama dalam bidang sains dan fisika. Jika dibaca berdasarkan perspektif kurikulum 2013 yang terdiri dari empat Kompetensi Inti (KI), setidaknya ada beberapa temuan yang dapat digarisbawahi. Pertama, aspek KI 1 (sikap spiritual) terdapat dalam bacaan qiräah halaman yang menceritakan bahwa Allah menurunkan al-Quran kepada rasulNya sebagai petunjuk bagi manusia dan dianjurkan bagi setiap muslim untuk membaca dan mempelajarinya. Dengan turunnya al-Quran, maka lahirlah ilmuilmu pengetahuan lain, seperti ilmu tafsir, ilmu figh, dan ilmu bahasa. Konten materi tersebut telah menyentuh ranah spiritual. Dengan demikian, guru sebagai fasilitator hendaknya dapat menyampaikan dengan baik.

\section{القراءة}

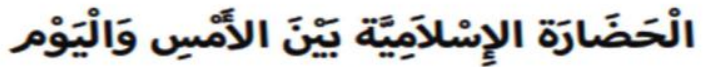

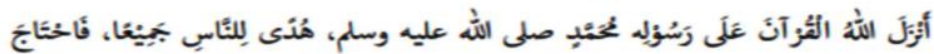

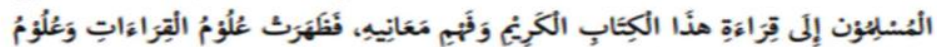

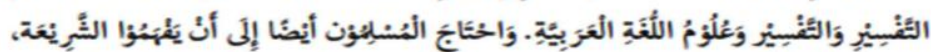

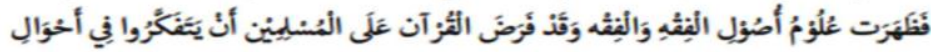

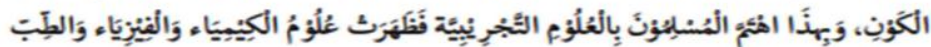

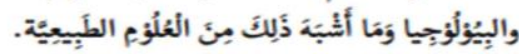

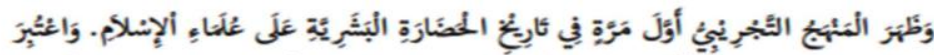

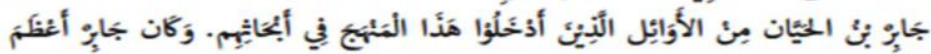

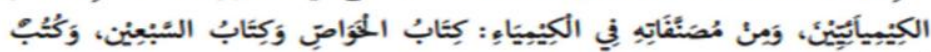

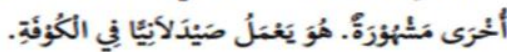

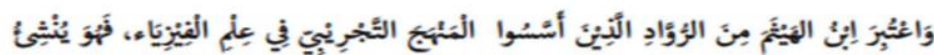

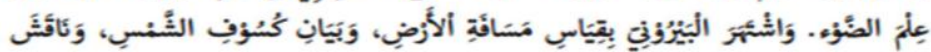

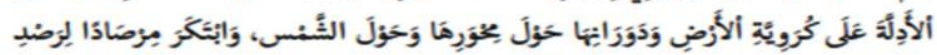

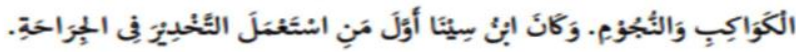

Gambar 1: Materi Bab Pertama

b. Bab Kedua

Pada bab kedua mengupas tentang الرحلات و الثقافة الإسلامية Rihlah dan Budaya Islam). Hiwār dalam bab dua berjudul التأثر بالثقافة الغربية (Pengaruh Budaya Barat). Sedangkan qirāah bertema الرحلات والثقافة (Rihlah dan Budaya). Pada biwār diceritakan dampak negatif dari budaya Barat yang cenderung 
mengarah ke pergaulan bebas. Materi ini dapat memberikan wawasan kepada siswa mengenai budaya Barat yang relatif dikonotasikan kurang baik. Namun di sisi lain, materi ini kurang seimbang. Karena di samping sisi negatifnya yang cenderung mengarah ke pergaulan bebas, budaya Barat juga mempunyai sisi positif, yakni terkait perkembangan ilmu pengetahuan. Di Barat, ilmu pengetahuan berkembang sangat pesat dengan berbagai penemuan modern yang dilakukan. Dewasa ini, pendidikan yang berkualitas justru terletak di belahan bumi bagian Barat, seperti Eropa dan Amerika. Banyak pelajar atau mahasiswa dari berbagai belahan dunia justru berharap bisa mengenyam pendidikan di negara-negara Barat.

Dalam konteks materi hiwār ini setidaknya telah menyentuh ranah sosial, spiritual, pengetahuan, maupun keterampilan siswa. Ranah spiritual dan sosial tersirat dalam kandungan teks biwär yang menceritakan dampak negatif budaya Barat. Dengan menghayati sungguh dan mempelajarinya, diharapkan siswa dapat berhati-hati dalam bertindak dan memiliki karakter religius dan berpegang teguh pada syariat Islam. Selain itu, akan memberikan pemahaman kognitif siswa akan bahayanya budaya bebas ala Barat dan dapat menjadi motivasi para siswa untuk mempraktikkan dalam kehidupan sehari-hari. Dengan kata lain, empat ranah KI dalam kurikulum 2013 telah terpenuhi dalam materi ini, meskipun perlu diadakan penyempurnaan.
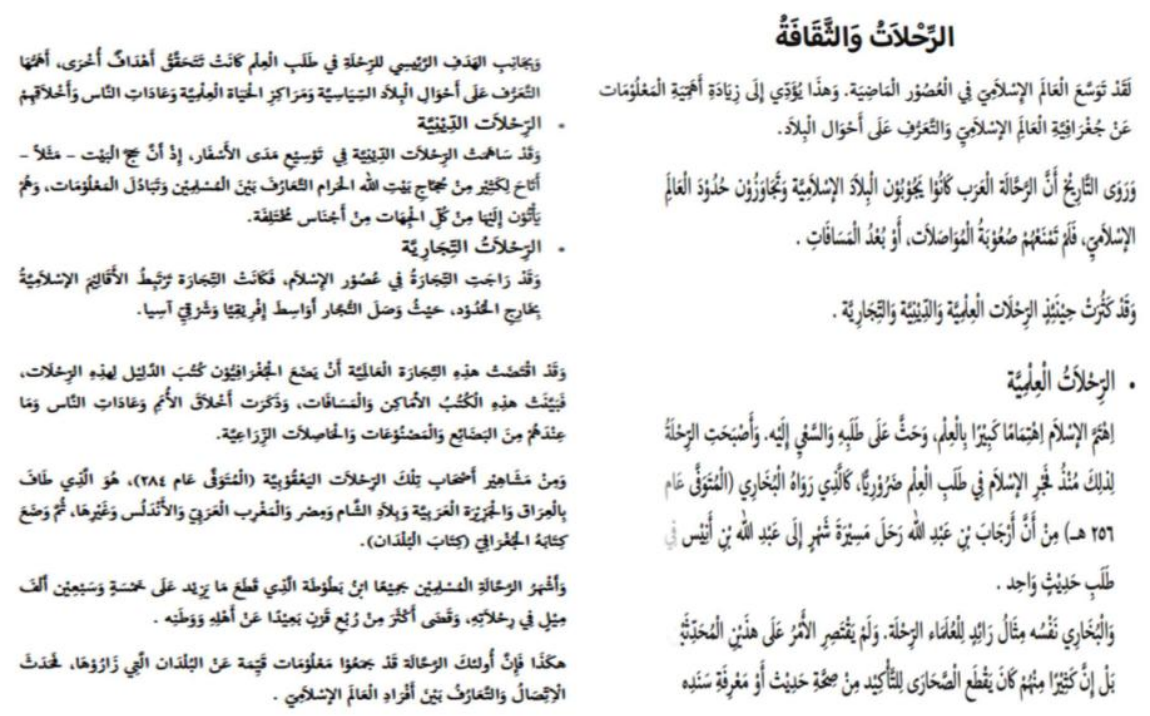

Gambar 2: Materi Bab Dua

c. Bab Tiga

Bab tiga berjudul الإمام البخارى (Imam Bukhāri) mengisahkan cerita dua tokoh besar dalam sejarah Islam: Ibnu Sina dan Umar bin Khātab. Dalam hiwār dikisahkan cerita Ibnu Sina yang merupakan pelopor lahirnya ilmu kedokteran 
pertama dalam Islam. Jika ditelaah lebih mendalam, meteri hiwār dalam bab tiga ini lebih banyak menyentuh ranah pengetahuan (KI 3) dan keterampilan (KI 4). Ibnu Sina yang dikenal sebagai ilmuan serta filosof Muslim yang banyak mempelajari sains, kedokteran, bahkan filsafat dan sangat berpengaruh dalam perkembangan ilmu kedokteran modern yang dikembangkan oleh Barat. Selanjutnya, dalam qirāah dikupas kisah Umar bin Khatāb yang memiliki kepekaan sosial tinggi. Hal tersebut tersurat dalam teks bacaan.

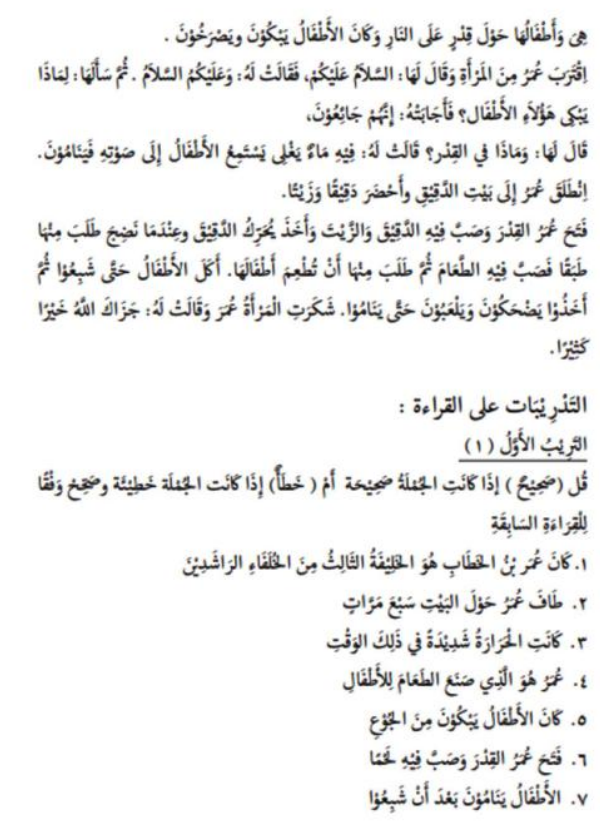

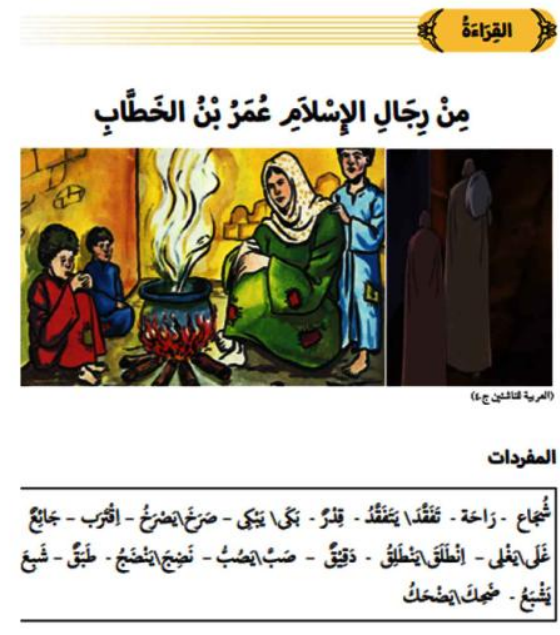

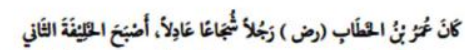

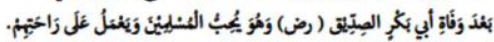

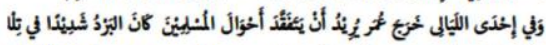

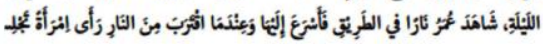

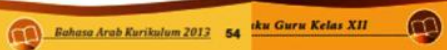

Gambar 3: Materi Bab Tiga

\section{d. Bab Empat}

Bab empat yang bertema الأعياد في الإسلام (hari-hari besar dalam Islam) menjelaskan mengenai hari-hari besar yang dirayakan oleh umat muslim. Jika dibaca berdasarkan perspektif kurikulum 2013 yang terdiri dari empat Kompetensi Inti (KI), setidaknya ada beberapa temuan yang dapat digaris bawahi. Pertama, aspek KI 1 (sikap spiritual) terdapat dalam hiwār dan qiräah yang menceritakan keadaan umat muslim pada malam hari raya hingga berlangsungnya hari raya tersebut. Mereka merayakan dengan memperbanyak takbir, tahlil, dan tahmid kepada Allah. Selain itu, nilai spiritual dapat dilihat ketika seluruh umat muslim melaksanakan pembayar zakat fitrah ketika hari raya idul fitri, dimana mengeluarkan zakat fitrah merupakan kewajiban setiap umat 
muslim untuk membersihkan hati, harta, maupun diri mereka. Konten materi tersebut telah menyentuh ranah spiritual. Dengan demikian, guru sebagai fasilitator hendaknya dapat menyampaikan dengan baik dalam memperkenalkan kewajiban seorang muslim mengenai pentingnya berzakat fitrah kepada peserta didik.

Kedua, setelah dipahami secara mendalam, tema dalam bab empat pun sudah menyentuh ranah sikap sosial (KI 2) yang terlihat dalam percakapan biwār yang berjudul "Hari Raya Idul Adha" dan dalam bacaan qiräah yang berjudul "Hari-Hari Besar dalam Islam". Dijelaskan bahwa dengan adanya hari raya tersebut tiap muslim dianjurkan untuk saling memaafkan, menyayangi satu sama lain, dan menyantuni fakir miskin. Nilai-nilai sosial terlihat dalam konten materi tersebut, bahwasanya diwajibkan bagi seorang Muslim untuk membayar zakat dan membagikannya kepada yang membutuhkan, baik orang-orang fakir maupun orang-orang miskin. Selain itu dapat dilihat pula ketika Idul Adha sebagian umat Muslim yang mampu akan membagikan daging kurban kepada orang-orang fakir dan orang-orang miskin. Selanjutnya, sikap sosial yang dapat dilihat dari konten materi ini ketika setelah selesai melaksanakan Sholat Ied, umat Muslim akan melakukan silaturrahim terhadap sanak keluarga dan handai taulan untuk saling memaafkan terhadap dosa dan kesalahan satu sama lain.

Oleh karena itu, konten materi ini dapat memupuk jiwa sosial peserta didik akan pentingnya saling menyayangi dan peduli terhadap sesama terutama terhadap orang-orang fakir dan miskin.

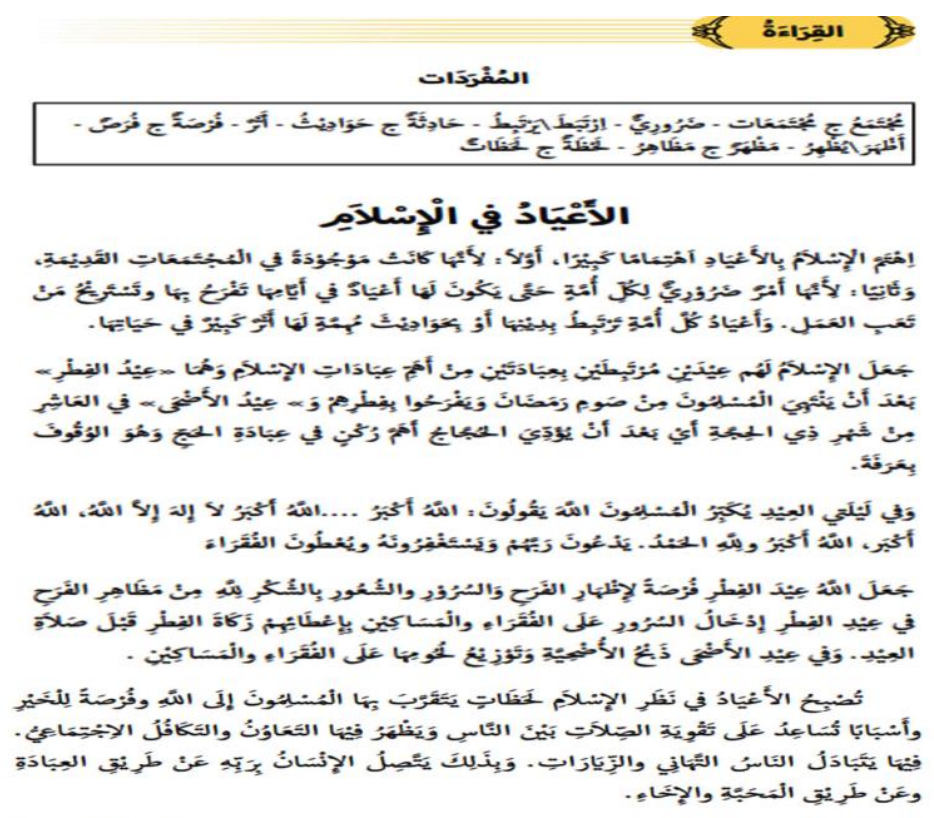

Gambar 4: Materi Bab Empat 
e. Bab Lima

Bab lima berjudul إبراهيم و البحث عن الخالق (Nabi Ibrahin Mencari Tuhan). Pada bab ini ranah spiritual ( KI 1) terdapat pada qirāah yang dijelaskan dalam beberapa ayat al-Quran tentang keyakinan Nabi Ibrahim terhadap keesaan Allah yang menciptakan seluruh alam raya ini. Hal ini akan memberikan pelajaran keruhanian bagi peserta didik akan pentingnya mengimani adanya Tuhan yang meciptakan seluruh jagat raya. Seorang guru harus memberikan penjelasan yang baik serta mengarahkan peserta didik untuk memiliki keimanan pada Tuhan sebagai hamba-Nya. Selanjutnya, ranah sosial ( KI 2) pada bab ini aspek sosial terdapat pada teks bacaan qirä'ah yang menceritakan kepatuhan Nabi Ibrahim terhadap ayahnya, dimana Nabi Ibrahim membantu ayahnya dalam membuat dan menjualkan patung-patung berhala ke pasar. Pada aspek ini mengajarkan bahwa kita dianjurkan untuk tetap patuh berbuat baik dan menghormati kedua orang tua, namun tidak mengikuti jalan keduanya yang mengajak pada kesesatan/mempersekutukan Allah. Sedangkan ranah pengetahuan (KI 3) terlihat saat proses Nabi Ibrahim dalam mencari tahu siapa Tuhan sesungguhnya yang menciptakan alam raya ini

\section{$\bar{\sigma}=\mathbf{a}$}

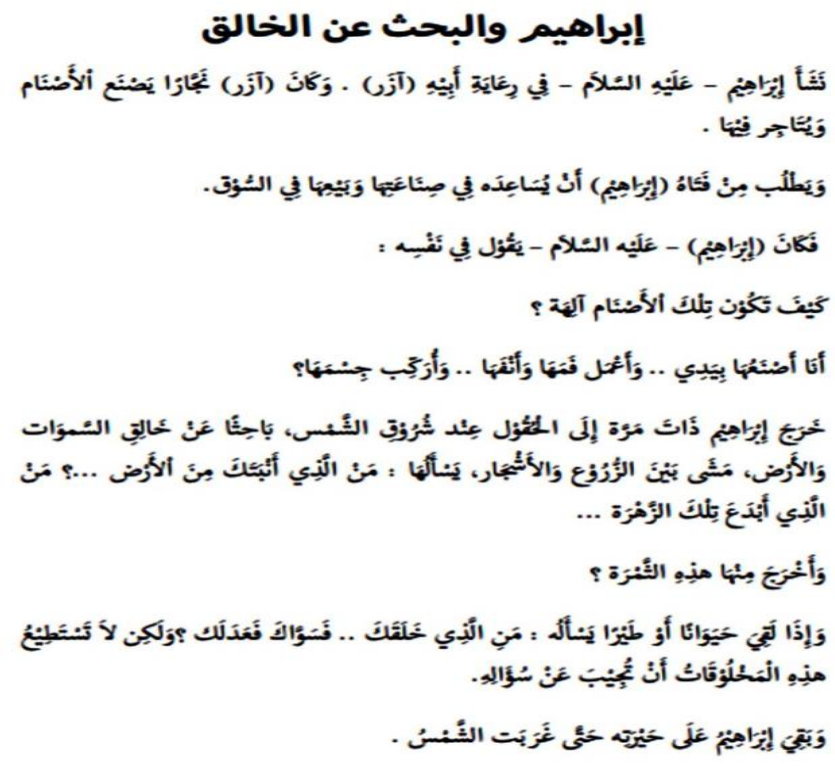

(D) Bohasa Arab Kurikulum 2013 96

Gambar 5: Materi Bab Lima 


\section{Analisis Isi Khiwār dan Qirā'ah Berdasarkan Kebutuhan Peserta Didik}

Setelah menelaah secara keseluruhan materi dalam buku ini, terdapat hal menarik yang perlu dicermati lebih lanjut. Secara umum keempat aspek dalam diskursus kurikulum 2013 yang meliputi aspek sikap spiritual, sikap sosial, pengetahuan, dan keterampilan sudah terpenuhi.

1. Ranah Sikap Spiritual

Peserta didik kelas XII merupakan generasi yang mulai beralih menuju tahap usia dewasa. Oleh sebab itu, sudah seharusnya mereka memiliki sikap spiritual dengan baik, baik dalam hal keimanan (teologi), maupun dalam hal ibadah (mu'amalah). Kalau dipetakan, buku siswa bahasa Arab kurikulum 2013 untuk MA kelas XII ini telah mencakup beberapa ranah spiritual, seperti aspek ketuhahanan, ibadah, maupun mu'amalah.

a. Aspek Teologi/Ketuhanan (keimanan)

Keimanan merupakan pokok yang sangat penting dan menjadi penopang ibadah seseorang. Sebanyak apapun ibadah seseorang kalau tidak didasari dengan keimanan maka akan sia-sia ibadah tersebut. Oleh sebab itu, aspek ini harus ditanamkan sedini mungkin kepada peserta didik. Dalam kaitannya dengan materi buku ajar ini, aspek keimanan yang disajikan setidaknya terdapat di bab lima yang bertema إبراهيم والبحث عن الخالق (Nabi Ibrahim Mencari Tuhan) pada bab ini menjelaskan materi mengenai ketuhanan, yang dikisahkan pencarian Nabi Ibrahim as terhadap kebenaran akan adanya Tuhan yang menciptakan alam raya, hingga ia mendapatakan petunjuk dari-Nya. Allah perlihatkan segala keagungannya kepada Nabi Ibrahim yang mana dijelaskan dalam al-Quran surah al-An'am 75-79 bahwasanya yang menciptakan alam raya ini adalah Tuhan semesta (Allah swt). Materi pada bab lima yang mengisahkan perjuangan Nabi Ibrahim sudah memiliki kriteria materi yang baik untuk disajikan untuk siswa kelas XII.

Materi yang dikemas dengan kisah-kisah perjuangan para nabi dalam menemukan jalan kebenaran dapat menstimulus dan memacu peserta didik dalam belajar agama ilmu tauhid. Kisah para nabi dengan problematika yang dihadapi ketika menyebarkan wahyu dari Allah dapat meningkatkan keimanan mereka terhadap ajaran agama jika kisah para nabi tersebut dapat dikemas dengan baik oleh guru.

b. Aspek Ibadah

Pada aspek yang memiliki nilai spiritual mengenai soal peribadahan terdapat pada bab empat dengan judul materi الأعياد في الإسلام (Hari-hari Besar Islam). Dalam materi ini diuraikan bahwa memperingati hari-hari besar dalam Islam merupakan suatu kebiasaan baik bagi umat Islam. Perayaan tersebut dianggap bagian dari rasa syukur mereka terhadap Allah swt. Hari-hari besar 
adalah hari raya Idul Fitri dan hari raya Idul Adha. Umat muslim dianjurkan memperingati hari raya Idul Fitri sebagi hari kemenangan bagi mereka yang telah melakanakan puasa di bulan ramadhan. Selain itu pada malam Idul Fitri umat Muslim dianjurkan untuk memperbanyak kalimat tahmid, tahlil kepada Allah, dan membayar zakat sebagai rukun Islam yang wajib ditunaikan. Sama halnya dengan peringatan hari raya Idhul Fitri, pada hari raya Idul Adha juga diperingati, yakni dianjurkan melaksanakan haji ke baitullah bagi yang sudah mampu baik segi materi dan kesehatan. Pada hari raya Idul Adha umat Muslim dianjurkan menyembelih hewan kurban setelah melaksanakan Salat Ied.

Selain materi di atas, dalam buku ajar ini juga mengandung materi-materi yang dapat menstimulus siswa untuk beribadah, seperti anjuran berpuasa dan zakat. Dengan demikian, akan memberikan pengetahuan bagi siswa dalam rangka mengamalkan ibadah wajib sebagai implementasi rukun Islam. Dalam buku ajar ini dirasa cukup memberikan materi tambahan bagi mereka selain di mata pelajaran khusus peribadahan ( ilmu figh). Sehingga materi ini dianggap cukup memenuhi syarat berdasarkan aspek spiritual yang dianggap cukup baik untuk kalangan siswa menengah atas.

2. Ranah Sikap Sosial

Dewasa ini kecapakan sosial menjadi hal yang cukup krusial dalam pembentukan karakter peserta didik. Berbagai peristiwa kekerasan yang kerap melibatkan peserta didik, seperti tawuran antar-pelajar, perkelahian, dan perbuatan amoral lainnya ditengarai akibat memudarnya nilai-nilai sosial dan menjadikan mereka tidak berkarakter serta cenderung tidak memiliki empati terhadap sesama. Oleh karenanya, materi buku ajar hendaknya turut mempunyai andil dalam menumbuhkan karakter sosial peserta didik, terutama peserta didik di sekolah lanjutan yang notabenenya belum memiliki kematangan berpikir dan rentan terhadap tindakan tak terpuji. Setelah menganalisis buku ajar bahasa Arab siswa kurikulum 2013, ada beberapa temuan penting terkait nilai-nilai sosial yang terkandung dalam materi buku ajar tersebut. Di antaranya:

a. Kecakapan Personal

Materi yang disajikan minimal mengajak peserta didik mengembangkan, mengenal kelebihan dan kekurangan, serta mengembangkan diri sendiri sebagai pribadi mandiri, makhluk sosial, dan makhluk ciptaan Tuhan yang jujur, disiplin, tanggung jawab, peduli, santun, responsif, pro-aktif, cinta damai, memiliki rasa ingin tahu, objektif, teliti, cermat, tekun, kritis, kreatif, dan inovatif. Pada buku teks ini, materi yang disajikan kurang lebih mampu menumbuhkan rasa ingin tahu, kritis, kreatif, inovatif, disiplin, tanggung jawab, peduli, dan santun kepada peserta didik. Uraian materi yang disajikan dalam buku teks mampu mengajak peserta didik untuk mengembangkan kecakapan hidup dan mampu berkomunikasi, berinteraksi, dan bekerjasama dengan orang lain untuk 
membentuk perilaku bermasyarakat (gotong royong, toleransi, bertanggung jawab, terbuka, dan cinta damai).

Mengacu pada ketentuan di atas, maka buku teks ini dirasa cukup memberi dorongan kepada peserta didik untuk memiliki kecakapan sosial melalui perintah bekerjasama atau diskusi dan tugas pengamatan fakta. Dalam tugas mandiri peserta didik akan mengerjakan tugas sesuai dengan keinginannya, sedangkan dalam kerja kelompok peserta didik tidak bisa hanya memperdulikan pendapatnya, tetapi juga pendapat teman-teman satu kelompoknya. Kerjasama dan berdiskusi tersebut akan mengajarkan peserta didik bagaimana cara gotong royong, toleransi, bertanggung jawab dan terbuka dalam menyelesaikan tugas kelompok. Hal ini tidak mudah bagi peserta didik yang tidak cukup memiliki kecakapan sosial, sehingga dengan banyaknya tugas kerjasama akan tumbuh kecakapan sosial peserta didik yang kelak akan digunakannya dalam lingkungan masyarakat.

b. Peduli Terhadap Lingkungan dan Sesama

Pada buku teks siswa bahasa Arab kurikulum 2013 terdapat beberapa materi yang menghantarkan siswa untuk memiliki sikap sosial yang diharapkan pada ranah ini, di antaranya pada bab tiga yang bertema Imam Bukhāri (الإمام (البخارى) yang menceritakan kisah umar bin khattab seorang pemimpin Islam kedua setelah abu bakar assidhiq. Ia dikenal sebagai pemimpin yang adil dan pemberani, perangainya lemah lembut, sehingga ia disukai oleh masyarakat. Dari kisah ini dapat kita lihat sikap sosial yang dimiliki seorang pemimpin yang dapat ditiru oleh seorang peserta didik mengenai sikap tanggung jawab, adil dan penuh perhatian terhadap sesama. pada materi bab empat pun memiliki nilai sosial yang bisa dipelajari oleh peserta didik, yakni berbuat baik dan berbagi terhadap fakir miskin.

Namun perlu dicatat di sini, nilai-nilai sosial yang terkandung dalam materi buku ini hanya mencakup interaksi nila-nilai sosial sesama Muslim. Nilai toleransi antar umat beragama belum tersentuh dalam materi buku ini. Meskipun siswa Madrasah Aliyah homogeny (semuanya Muslim), tidak menutup kemungkinan di luar sekolah mereka berinteraksi dan berbaur dengan pemeluk agama lain. Untuk itu, nilai-nilai sosio-kultural yang berbasis religi perlu diperkenalkan agar mereka tidak rigit jika mendapat perbedaan. ${ }^{21}$ Menurut penulis, penanaman nilai-nilai toleransi tersebut sangat diperlukan, mengingat dewasa ini intoleransi telah merambah di kalangan peserta didik usia madrasah aliyah yang masuk kategori usia millennial. Oleh karena itu, diperlukan

${ }^{21}$ Miftahur Rohman dan Mukhibat, "Internalisasi Nilai-Nilai Sosio-Kultural Berbasis Etno-Religi Di MAN Yogyakarta III," Edukasia $\square$ : Jurnal Penelitian Pendidikan Islam 12, no. 1, 2017, hlm. 31-56. 
internalisasi nilai-nilai pendidikan agama yang humanis serta multikulturalis. ${ }^{22}$ Pendapat ini didukung oleh data hasil penelitian PPIM UIN Jakarta yang menyebutkan bahwa pendidikan agama yang mempengaruhinya untuk tidak bergaul dengan pemeluk agama lain. Selain itu, opini intoleran juga ditemukan di sebagian guru/dosen pendidikan agama Islam. Sebanyak 33.9\% guru/dosen memiliki opini intoleran terhadap sesama pemeluk agama dan $29 \%$ intoleran terhadap pemeluk agama lain. Sedangkan pada level aksi, nampak bahwa adanya dua perbedaan signifikan antara aksi toleransi internal dan aksi radikal. Dimana guru mempunyai kecenderungan kuat memiliki perilaku sangat intoleran pada kategori aksi toleransi internal (69.3\%), sedangkan pada kategori aksi radikal $8.4 \%$ dan pada kategori aksi toleransi eksternal $24.2 \%{ }^{23}$

Hasil penelitian di atas cukup mengejutkan, di mana opini intoleran dan radikal tergolong tinggi baik di kalangan siswa dan mahasiswa, maupun di kalangan guru dan dosen yang notabenenya sebagai pendidik yang semestinya menyemaikan nilai-nilai toleransi kepada generasi bangsa ini. Selain contoh tersebut, kalau kita flasbback ke belakang tentu kerap dijumpai peristiwa-peristiwa kekerasan yang melibatkan pelajar kita, baik kekerasan verbal maupun kekerasan fisik yang mengarah pada tindakan persekusi dan intimidasi

3. Ranah Pengetahuan

Ranah pengetahuan dalam buku ini secara garis besar dibedakan menjadi pengetahuan umum dan pengetahuan agama. Pengetahuan umum terdapat dalam kisah Ibnu Sina, sedangkan ranah pengetahuan agama terdapat dalam kisah Imam Bukhari. Kedua kisah ini tertuang dalam konten materi yang disajikan dalam bentuk bacaan maupun percakapan yang terdapat pada bab pertama dan tiga.

Bab pertama memiliki ranah pengetahuan yang bisa dijadikan rujukan bagi peserta didik dalam memahami ilmu pengetahuan. Contohnya dalam kisah beberapa ilmuwan dan filosof Muslim dalam bidang Fisika, Kimia, dan Kedokteran, seperti Jābir bin Hayyān, Ibnu Sina, dan Ibnu Haitsam. Jābir bin Hayyān pencetus ilmu Kimia, Ibnu Sina pencetus ilmu kedokteran dan dia pun dokter pertama dalam sejarah. Selain itu filosof terkenal dalam ilmu matematika yakni Ibnu Jābir al-Battāni, al-khawārizmi, dan al-Biruni.

Materi di atas setidaknya akan memacu motivasi siswa untuk mempelajari berbagai pengetahuan umum, seperti sains dan teknologi. Peminatan siswa Madrasah Aliyah terhadap ilmu pengetahuan harus diseimbangkan antara pengetahua sains dan agama. Dikotomi yang kerap

\footnotetext{
${ }^{22}$ Miftahur Rohman, "Tinjauan Filosofis Guru Pendidikan Agama Islam HumanisMultikulturalis," Ta'allum: Jurnal Pendidikan Islam 6, no. 1 (2018), hlm. 151-174.

${ }^{23}$ Rangga Eka Saputra, “Api Dalam Sekam: Keberagamaan Generasi Z," Convey Report 1, no. 1 (2018), hlm. 1-54.
} 
disematkan dalam pendidikan Islam harus dilokalisir sedini mungkin agar output yang dilahirkan oleh madrasah tidak melulu mereka yang menguasai pengetahuan agama saja, tetapi juga pengetahuan umum. Selain itu, materi yang mengisahkan para filosof Muslim tersebut bisa dijadikan rujukan untuk memperkenalkan kepada peserta didik terkait ilmuan-ilmuan Muslim di abad pertengahan yang memiliki kontribusi dalam perkembangan peradaban Barat.

Secara umum materi yang dikemas dalam buku ajar ini memotivasi siswa untuk mempelajari ilmu-ilmu agama. Hal ini terlihat dalam materi tentang "peradaban Islam pada masa dahulu dan saat ini" yang mana menceritakan bahwa pertama kali Allah menurunkan al-Quran kepada rasul-Nya sebagai petunjuk bagi manusia, dan dianjurkan bagi setiap muslim untuk membaca kitabullah ini serta memahami maknanya. Maka sejak itulah muncul ilmu membaca, ilmu tafsir, dan ilmu bahasa Arab. Umat muslim juga dianjurkan untuk memahami syariat Islam. Oleh karenanya muncullah ilmu ushul fiqh dan fiqh.

\section{Kesimpulan}

Ditinjau berdasarkan kurikulum 2013 yang menjadi perspektifnya, secara umum buku ini telah memenuhi empat unsur keterampilan, yakni ranah sikap spiritual (KI), sikap sosial (KI 2), pengetahuan (KI 3), dan keterampilan (KI 4). Dalam setiap bab-nya, buku ini memiliki kecondongan yang beragam. Bab pertama dan kedua lebih banyak menyentuh ranah sikap spiritual (KI 1) dan pengetahuan (KI 3), bab tiga dan empat lebih banyak menyentuh ranah pengetahuan (KI 3) dan sikap sosial (KI 2), dan bab terakhir lebih ke ranah sikap spiritual (KI 1). Jika dikaitkan dengan wabah intoleransi yang dewasa ini mudah merebak di kalangan pelajar SMA/MA, ranah sosial (KI 2) dalam buku ini belum sepenuhnya terpenuhi. Dalam buku ini tidak disajikan materi tentang keberagaman, multikultural, dan bentuk toleransi, khususnya yang melibatkan pemeluk agama-agama.

Dalam penulisan buku ajar diharapkan memperhatikan aspek kebhinekaan, sehingga akan tertanam nilai multikultural diri peserta didik. Kementerian Agama sebagai pihak yang mengeluarkan buku ini diharapkan menyempurnakan penulisan buku ajar tersebut dengan menyisipkan nilai-nilai toleransi, kebinekaan, dan perbedaan. Lembaga pendidikan hendaknya lebih jeli dalam memilih buku ajar yang akan digunakan. Buku ajar haruslah sesuai dengan SK dan KD, dapat memberikan pengetahuan, keterampilan, serta nilai dan sikap yang harus dipelajari peserta didik untuk mencapai standar kompetensi yang telah ditentukan. 


\section{Bibliografi}

Abusyairi, Khairy. "Pengembangan Bahan Ajar Bahasa Arab.” Dinamika Ilmu 13, no. 1 (2013).

Al-Qashiri, Maufiq Abdullāh. Asytarạt äti Maqtarahata Lā 'adāda Al-Kitāb AlTa'limi Fì Al-Lughati Al-'Arabiyyah. Kuala Lumpur: al-Jami'ah alWathaniyah, n.d.

Amrullah, Muhammad Afif. "Analisis Kesalahan Penerapan Qawa'id Pada Buku Ajar Bahasa Arab." Al-Tadækiyyah: Jurnal Pendidikan Islam 6, no. 1 (2017): $46-65$.

Hamzah, Zaki Al. "Beredar Buku Pelajaran SD Berbau Porno." http://m.republika.co.id/berita/koran/news-update/13/07/10/mpg3lgberedar-buku-pelajaran-sd-berbau-porno, diakses tanggal 11 Agustus 2018.

Kartodirdjo, Sartono, and Sarwono Pusposaputro. Pendekatan Imu Sosial Dalam Metodologi Sejarah. Gramedia Pustaka Utama, 1992.

Kurnia, Feni, and Apit Fathurohman. "Analisis Bahan Ajar Fisika Sma Kelas Xi Di Kecamatan Indralaya Utara Berdasarkan Kategori Literasi Sains.” Jurnal Inovasi dan Pembelajaran Fisika 1, no. 1 (2014): 43-47.

Ma'arif, M Syamsul. "Perbandingan Kualitas Buku Teks Bahasa Arab Tingkat Madrasah Tsanawiyah.” Jurnal Pendidikan Islam 4, no. 1 (2015): 209-234.

Moleong, Lexy J. Metodologi Penelitian. PT. Remaja Rosda Karya. Bandung, 1999.

Muslich, Masnur. Text Book Writing: Dasar-Dasar Pemahaman, Penulisan, Dan Pemakaian Buku Teks. Ar-Ruгz Media. Yogyakarta, 2010.

Rohman, Miftahur. "Tinjauan Filosofis Guru Pendidikan Agama Islam Humanis-Multikulturalis." Ta'allum: Jurnal Pendidikan Islam 6, no. 1 (2018): 151-174.

Rohman, Miftahur, and Mukhibat Mukhibat. "Internalisasi Nilai-Nilai SosioKultural Berbasis Etno-Religi Di MAN Yogyakarta III." Edukasia : Jumal Penelitian Pendidikan Islam 12, no. 1 (February 1, 2017): 31-56. http://journal.stainkudus.ac.id/index.php/Edukasia/article/view/1771.

Salahudin. "Ada Unsur Porno, Buku Penjasorkes SD Kelas V Di Banyumas Ditarik." http://daerah.sindonews.com/ read/11608653/22/ada-unsurporno-buku-penjasorkes-untuk-sd-kelas-v-di-banyumas-di-tarik, diakses 
tanggal 11 Agustus 2018.

Sanusi, M. "Heboh! LKS Berbau Pornografi Di Malang." dalam http://daerah.sindonews.com/read/ 1086437/heboh-lks-bahasa-jawamesum-di-kota-malang, diakses tanggal 11 Agustus 2018.

Saputra, Rangga Eka. "Api Dalam Sekam: Keberagamaan Generasi Z." Convey Report 1, no. 1 (2018): 1-54.

Sticsher, Stefan. "Dkk, Metode Analisis Teks \& Wacana, Terj. Gazali Dkk." Yogyakarta: Pustaka Pelajar, 2009.

Susanti, Rini Dwi. "Studi Analisis Materi Ajar "Buku Teks Pelajaran "Pada Mata Pelajaran Bahasa Arab Di Kelas Tinggi Madrasah Ibtidaiyah." Arabia 5, no. 2 (2016).

Taufiqurrahman, Muhammad. "Menko Puan Minta Buku 'Aku Berani Tidur Sendiri' Diinvestigasi." dalam http://m.detik.com/news/berita/d3428466/menko-puan-minta-buku-aku-berni-tidur-sendiri-diinvestigasi, diakses tanggal 11 Agustus 2018.

Wassid, Iskandar, and Dadang Sunendar. Strategi Pembelajaran Babasa. Bandung: PT. Remaja Rosdakarya, 2008.

Widodo, Sembodo Ardi. "Model-Model Pembelajaran Bahasa Arab." AlArabiyyah jurnal PBA 2 (2006).

Zulhanan, Zulhanan. "Model Pembelajaran Bahasa Arab Komunikatif." Jurnal Al Bayan: Jurnal Jurusan Pendidikan Bahasa Arab 6, no. 2 (2017). 